\title{
Notes on the vocalizations of Golden Cuckoo-shrike (Campochaera sloetii)
}

\section{Peter Boesman}

In the following we briefly analyze and compare voice of the two races of Golden Cuckooshrike (Campochaera sloetii). We also try to quantify the extent of any vocal differences using the criteria proposed by Tobias et al. (2010), as a support for taxonomic review.

We have made use of sound recordings available on-line from Xeno Canto (XC) and Macaulay Library (ML).

Song of both races is structurally similar, a series of short stuttered notes followed by or interspersed with one or more melodious whistles.

Some examples:

sloetii (Northern region)

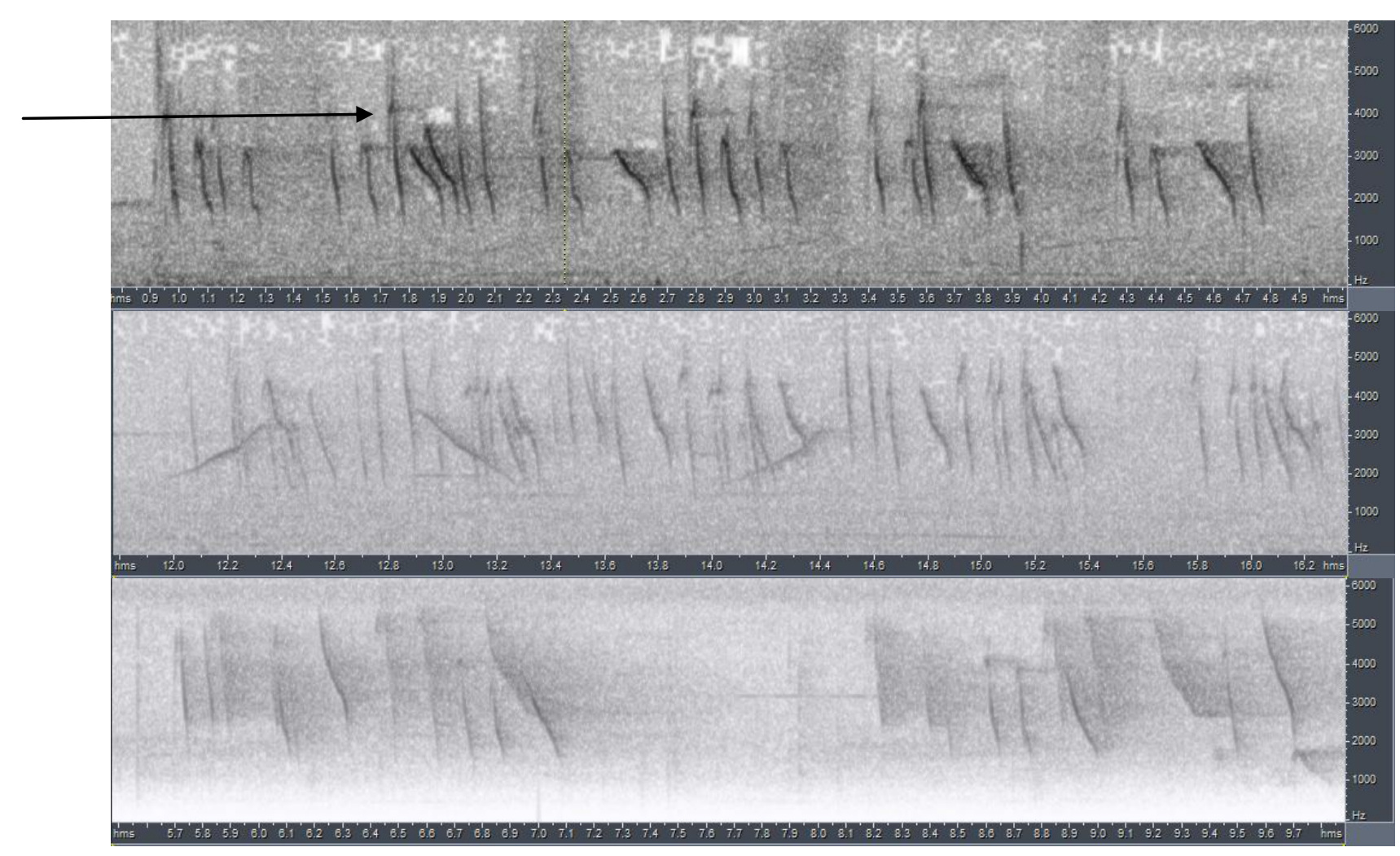




\section{HANDBOOK OF THE \\ BIRDS PF/THE WORLD \\ Aluve}

\section{ORNITHOLOGICAL NOTES}

flaviceps (Southern region)
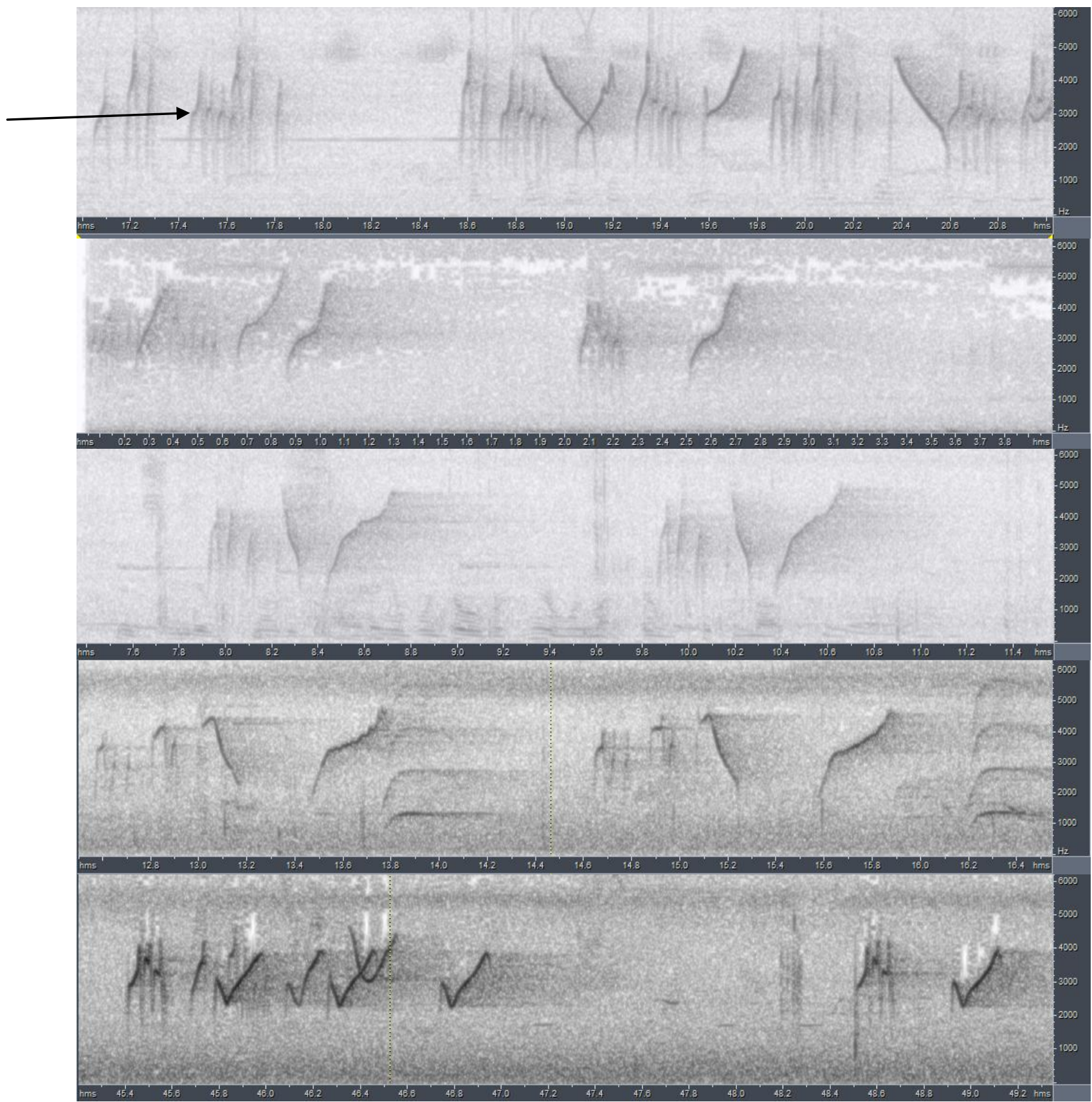

There seem to be slight differences in voice between both races:

sloetii has less upslurred whistles, and if present, these never are as rising as in flaviceps (score 1). Shape of the short stuttered notes is also slightly different, more variable in sloetii with 'bend in shape' not as clear-cut as in flaviceps (see arrows) clearly audible as different sounding (score 1). Using Tobias criteria as a guidance, this would lead to a total vocal score of about 2. 
This note was finalized on 4th November 2015, using sound recordings available on-line at that moment. We would like to thank in particular the sound recordists who placed their recordings for this species on XC and ML: Scott Connop, Frank Lambert, Hans Matheve, John $\checkmark$ Moore and Bas Van Balen.

\section{References}

Tobias, J.A., Seddon, N., Spottiswoode, C.N., Pilgrim, J.D., Fishpool, L.D.C. \& Collar, N.J. (2010). Quantitative criteria for species delimitation. Ibis 152(4): 724-746.

\section{Recommended citation}

Boesman, P. (2016). Notes on the vocalizations of Golden Cuckoo-shrike (Campochaera sloetii). HBW Alive Ornithological Note 179. In: Handbook of the Birds of the World Alive. Lynx Edicions, Barcelona. (retrieved from http://www.hbw.com/node/932115 on 23 August 2016). 